\title{
" Special and Differential Treatment in
}

the Millennium Round"

John Whalley

CSG R Working Paper No. 30/ 99

May 1999
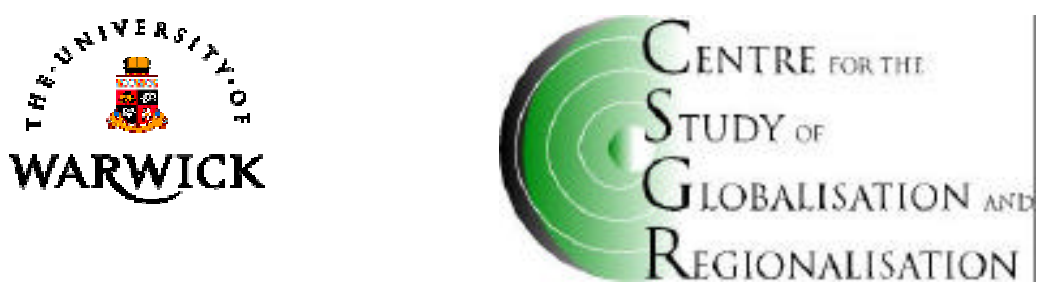

E.S.R.C
ECONOMIC
\&SOCIAL
RESEARCH
COUNCIL 


\title{
Special and Differential Treatment in the Millennium Round \\ John Whalley ${ }^{1}$ \\ Univesities of Warwick and Western O ntario, and NBER \\ CSG R Working Paper No. 30/ 99 \\ May 1999
}

\begin{abstract}
:
This paper discusses special and differential treatment (SDT) for developing countries in a new WTO trade round. It argues that SDT introduced in the Uruguay Round represented a sharp departure from pre Uruguay Round SDT which had focussed on special rights to protect and preferential market access, and was characterised by a wide range of delays, exemptions, best efforts endeavours from developed countries, technical assistance and other provisions. These new provisions were arrived at late on in negotiation, and were ad hoc in design. They nonetheless represented a new form of SDT relating to special rights needed on adjustment and policy capacity grounds as developing countries integrated into the WTO system. Despite general skepticism as to the value of SDT benefits, the challenge is to more carefully rationalise and target these provisions, and to elaborate on them.
\end{abstract}

Keywords: Millennium Round, Developing Country, World Trade Organisation (WTO), Special and Differential Treatment (SDT).

Address for correspondence:

John Whalley

CSGR

University of Warwick,

Coventry CV4 7AL

United Kingdom

Email: J.Whalley@warwick.ac.uk

\footnotetext{
${ }^{1}$ I am grateful to John Cuddy, William Martin, Adrian Otten, Paul Shanahan, Hesham Youssef, Fauzya Moore, Frederick Pratty, Peter Tulloch, Alan Winters and Natalie Zourin for conversations and information. CSGR is grateful for the financial assistance provided by the UK's Department for International Development in producing this paper. No part of this paper should be construed in any way as an expression of HM Government policy.
} 


\section{INTRODUCTION}

This paper discusses trade arrangements for developing countries under the heading of special and differential treatment (SDT) in the upcoming WTO Millennium Round. If actually launched in Seattle in December, this will be the $9^{\text {th }}$ post-war round under GATT/WTO, and the current speculation is that fresh discussion of SDT will be part of the negotiating mandate, although exactly how large a part remains to be seen.

Whether SDT has, in reality, simply become a convenient negotiating slogan since the term is enshrined in earlier GATT disciplines and a reference to it prior to making any concrete demand adds legitimacy to the request; or whether there remains an intellectually credible line of argument for a new form of SDT is the issue. Working out a new framework for SDT that can guide a meaningful negotiation is the challenge for the run up to Seattle.

The paper highlights the evolution of thinking of SDT from the believed development needs of the 1960 's involving special rights to protect and special rights of access to export markets; to the 1980's when the search for rights to protect gave way to unilateral liberalization and questioning as to whether any significant benefits had been achieved under SDT; to the Uruguay Round where in the name of SDT and special adjustment problems a whole array of delays on implementation, exemptions, and best efforts endeavours were introduced. It also highlights how the world has changed over the years, with unilateral liberalization in developing countries, ever more heterogeneity among developing countries, and most recently rapidly growing South-South trade. 


\section{THE MEANING OF SPECIAL AND DIFFERENTIAL TREATMENT}

\subsection{The Term "Special and Differential"}

The term special and differential treatment in the GATT evolved from debates in the1960's as to how the growth and development of developing countries was best facilitated by trade rules. It referred to GATT rights and privileges given to developing countries, but not extended to developed countries, and reflected a long history of calls by developing countries for special treatment in global trade arrangements. ${ }^{2}$ The term itself derived from a reference in the 1973 Tokyo Round Declaration which recognized "the importance of the application of differential measures in developing countries in ways which will provide special and more favourable treatment for them in areas of negotiation where this is feasible". Special and differential in this form denoted both an access and a right to protect component.

The ways in which these two components appeared in the GATT of the late 1970's are set out in summary form in Table 1. In terms of formal GATT/WTO benefits, developing countries were given special treatment under Article 18, Article 28 bis(iii), Part IV of the GATT and the 1979 framework agreement, commonly known as the Enabling Clause. Article 18 was the GATT's first attempt in 1954 to accommodate developing country concerns within its trade rules, and involved three separate components. Article 18A allowed for developing countries to renegotiate tariff bindings in order to promote the establishment of particular industries; any developing countries using this, however, was expected to offer compensation or face retaliation. Article 18B was about the use of balance of payments justified measures by developing countries; the 18B criteria for

\footnotetext{
${ }^{2}$ See the discussion of special and differential and its evolution in Hudec (1987) and Whalley (1990).
} 


\section{$\underline{\text { Table } 1}$}

\section{Key Elements of Special and Differential Treatment as they had entered GATT by the late 1970's}

\section{Special Rights to Protect}

- GATT (1994) Article 18B - Consultations with GATT BoP Committee over claimed exempt measures every 2 years rather than 1 year as under Article 12.

- GATT (1994) Articles 18A \& C - Tariff discretion allowed for infant industry purposes, and more broadly in tariff binding renegotiations; but compensation required.

- GATT (1994) Article 28 bis(iii) recognizes needs of developing countries to be taken into account in tariff negotiations.

2. Special Rights of Access

- 1971 GATT Article 25 Waiver for 10 years which allows for GSP schemes. Country GSP schemes

\section{Other Provisions}

- Part IV of GATT (1965) - 3 Articles $(36,37,38)$ which recognizes the development needs of developing countries in the trading system, as well as stating the principle of non-reciprocity.

- 1979 Tokyo Round Enabling Clause - makes earlier (1971) GATT Waiver for GSP permanent - introduces concept of graduation.

imposing trade restrictions involves slightly weaker formal criteria than those which apply to developed countries under Article 12. Article 18C allowed developing countries to use quantitative restrictions for infant industry purposes; however, as with Article 18A, Article 18C provided for compensation and retaliation in the absence of any negotiated agreement. Article 28 bis(iii) was a commitment that developing countries use of tariffs for economic development and fiscal purposes should be taken into account in tariff negotiations. All of these were benefits justified as special rights to protect. Part IV of the GATT sets out various acknowledgments of the special development needs of developing countries and concedes the principle of non reciprocity by developing countries in trade negotiation. 
In terms of special rights of access, the 1971 Waiver from Article 1 (MFN) obligations was the GATT arrangement that paved the way for trade preferences under the various developed country preferential tariff schemes under the Generalized System of Preferences. The 1979 Enabling Clause made the 1971 GSP waiver permanent, but also introduced the idea that special and differential treatment is not a permanent right. Developing countries would at some point graduate from special and differential treatment as they grew and developed.

\subsection{The Ideas Behind SDT}

The intellectual underpinnings of these SDT arrangements in GATT go back to the1950's and even earlier, as Table 2 indicates. It was widely believed in the early 1950s that balance of payments problems for developing countries were endemic to low income status, and that all developing countries would face permanent balance of payments problems. It was believed that it was impossible for most developing countries to liberalize since such actions would only widen their trade deficits. It was also believed that it was also desirable for developing countries to use protection on infant industry grounds, in part because of the perceived experience of Japan (that protected industries were able to generate export growth only after a period of relying on domestic markets). These arguments were complemented by reference to the Singer-Prebisch thesis, dating from the 1950's, which argued that developing countries always face a secular decline in their terms of trade; suggesting that developing countries would need to be given preferential access to developed country markets to offset these effects. 


\section{Table 2}

\section{The Motivation Behind Pre Uruguay Round Special and Differential Treatment}

1. Special Rights to Protect

- Balance of Payments Problems - Thought to be endemic to low income status.

- Infant Industry Arguments - Fledgling industries need an initial period of protection to grow in a secure domestic market, before eventually competing abroad.

- Development Strategy Considerations - Socially desirable to move resources from traditional (average product priced labour) agriculture to modern industrial sector (marginal product priced labour). Protection facilitates this.

2. Special Rights of Access

- Trade preferences needed to offset the ongoing decline in developing country terms of trade (commodity exporters) - the Singer Prebisch thesis.

3. A Negotiating Approach

- Developing countries have common problems which are special and different from those of developed countries. They should negotiate as a bloc, not individually; and stress enhancement of SDT as a right and insist on non-reciprocity.

\subsection{SDT Through The Tokyo Round}

The arguments above lead to the creation of UNCTAD in 1964, the introduction of Part IV (the 3 final GATT articles) into the GATT in 1965, and to a developing country negotiating strategy in the Tokyo Round of non reciprocity. Part IV has the title Trade and Development; and Article 36 recognizes the development needs of developing countries, the importance to them of improved market access, price stabilization, diversification of economic structures and inter-agency cooperation. It also contains a clear statement of the principle of non-reciprocity, ie that developing countries should not need to reciprocate trade concessions made to them by developed countries in negotiation. Article 37 represents a best efforts commitment (with no obligation for action) to the prioritization of products of interest to developing countries in any trade liberalization. Article 38 
provides for joint developed-developing country actions, citing possibilities for actions in the commodities field, inter-agency cooperation, possibilities of studying the export potential of developing countries, and other related issues.

Part IV of the GATT did not provide for a GATT Article 1 exception for developing country trade preferences, although it did contain the first formal statement in a GATT legal text of the principle of non-reciprocity. Only later in UNCTAD 2 in New Delhi in 1968 did the United States finally consent to participate in the global system of preferences and on the condition that they "be limited to tariffs, should be temporary, should be based on voluntary experience and should be extended by all of the developed countries to all of the developing countries on an MFN basis". The generalized system of preferences (GSP) for developing countries resulted from the granting of a ten year waiver in the GATT in 1971 for such schemes, even though the United States did not implement their GSP scheme until 1975.

In the Tokyo Round, developing country activities were largely aimed at formalizing and codifying SDT. At the beginning of the Round (in 1973) special and differential treatment to developing countries amounted to Article 18, Article 28 bis(iii) and Part IV. In addition, preferences extended under GSP were covered by a ten year Article 25 waiver that would have expired in 1981.

Among the Tokyo Round results were four framework agreements, the most important being titled "differential and more favourable treatment, reciprocity and fuller participation of developing countries" better known as the Enabling Clause; generally considered to be the centrepiece of the results on special and differential treatment from the Tokyo Round. The Enabling Clause provides a permanent legal basis for GSP schemes, similar special and differential treatment under Tokyo Round Codes, and under certain circumstances covers regional and global preferential agreements 
among developing countries. The Enabling Clause also contained a concession to the developed countries that developing countries recognize that as their economies get stronger they will participate more fully in the GATT framework of rights and obligations. The concept of graduation thus assumed a prominent place in discussions on special and differential treatment.

It is also worth noting that the term special and differential in this period took on connotations outside its formal representation in GATT legal disciplines; the notion being that special and differential also defined the special treatment of developing countries in the trade regime in an adverse sense. Hence, textile arrangements under the Multifibre Agreement yielding quota restrictions on developing country exports of textiles and apparel products were seen by some as a form of reverse special and differential treatment accorded developing countries in their trade dealings with developed countries. Also fitting into the same category were voluntary export restraints and trade arrangements in agriculture. Thus on the eve of the Uruguay Round the term special and differential treatment denoted a series of GATT arrangements in favour of developing countries, a negotiating approach based on non-reciprocity, and an orthogonal set of GATT inconsistent adverse measures affecting developing countries. 


\section{SPECIAL AND DIFFERENTIAL TREATMENT IN THE URUGUAY ROUND}

In the Uruguay Round special and differential treatment evolved further from its Tokyo Round meaning and in two important ways. One saw a change in the interpretation of special and differential from a negotiating point of view. The other involved a changed intellectual basis for the content of special and differential as embodied in the decisions of the Round at its conclusion in 1994.

\subsection{A Changed Negotiating Approach}

In the Uruguay Round developing countries showed themselves to be surprisingly willing to move away from the blocwide special and differential non-reciprocal approach to trade negotiation they had followed in the earlier Tokyo Round. The launch of the Uruguay Round and the period that followed overlapped with a period of sweeping intellectual change on trade policy in developing countries, and sharp moves towards unilateral liberalization. ${ }^{3}$

As Table 3 indicates, the emergence of meritocractic trade officials, initially in Latin America and later elsewhere was one factor. With training typically in North America and European graduate schools, they believed in the virtues of the gains from trade and unilateral liberalization. Their view was that outward oriented economies in the Pacific (primarily Korea and Taiwan) had demonstrated the value of outward orientation and hence the need to liberalize, and unilaterally if need be. The equally firmly held belief that developing countries had not in fact achieved much in terms of economic development benefits through trade protection was a further factor.

${ }^{3}$ See the discussion of Latin American reforms in Rajapatirana, de la Mora, and Yatawara (1997), and African reforms in Sorsa (1996) and Collier, Guillaumont, Guillaumont, and Gunning (1997). 


\section{$\underline{\text { Table } 3}$}

\section{Factors Behind The Reevaluation of SDT from the mid 1980's on}

\section{Economic Performance and the Stance of Trade Policy}

- Economic theory teaches the gains from trade, and open trade as the best policy for small countries.

- The countries who had successfully grown were outward oriented (Korea, Taiwan, Hong Kong, Singapore) not closed and protected.

- Protectionist policies create corruption (quota allocation schemes), rent seeking behaviour (again quota allocation schemes), and can lead to market concentration domestically.

\section{The Valuation of Benefits from SDT}

- GSP in application had been product constrained, and limited by competitive criteria.

- GSP concessions were not bound in GATT. Their threatened removal was used as a form of bilateral pressure on developing countries (intellectual property in Asia).

- The value of GSP preferences fell as tariffs broadly fell.

- The ability to use protection under Article 18B rested not on the letter of the article, but on its lax application (many countries not called for consultations) and an implicit developed-developing country deal (VER's in OECD for Article 18B defended measures).

- The benefits of protection were anyway doubted as they restricted the gains from trade.

3. Country Heterogeneity and the Weakening of Bloc Wide Negotiating Strategy

- Many developing countries pursued country rather than bloc wide interest; and opposed each other on certain issues (eg. Agriculture).

\section{Unilateral Liberalization}

- Wave of unilateral liberalization in trade policy swept the developing world; argument of need for special rights to protect greatly weakened.

5. Consolidation of Developing Country Negotiating Focus on Unifying Issues

- In opposing new issues (first services, then intellectual property) developing countries initially perceived a common and unifying interest.

- Textiles/Apparel also accepted as a common interest (but also partially cutting across countries)

\section{Refocusing SDT on Least Developed}

- Higher income rapidly growing economies (Korea, Taiwan) thought to no longer need SDT. Idea was to refocus prevailing SDT benefits on least developed. 
Country after country also adopted negotiating approaches in the Uruguay Round under which they pursued national interest more than blocwide interest as in previous Rounds. This was manifest particularly in the agricultural area with the formation of the Cairns Group and the active participation of Argentina, Brazil, and Thailand, all of whom had clear trade negotiating objectives of enhancing their export access. On the other hand, developing countries who were net importers of food (Jamaica, Egypt, Peru) foresaw losses from limits on export subsidies used by major food exporters (the EU, in particular), and argued strongly against liberalization in agriculture. In the agricultural area then, negotiating developing countries took different sides on the same issue.

While special and differential was far from abandoned as a principle in the Uruguay Round, the developing country negotiating approach evolved to be one of protecting and preserving what was there in SDT rather than pushing for further enhancement. Priority was placed on other negotiating areas, including textiles, agriculture, and dispute settlement. The reasons for this negotiating approach were many. There was weakened intellectual commitment to import substitution as noted above. What special and differential had gained developing countries in concrete policy and economic performance terms was also queried (see Appendix B). Also, the differences between individual developing countries (large/small/middle income; least developed; industrialized; commodity exporters; agriculture importers/exporters and other differences) had become such that in the Uruguay Round the grand coalition of all developing countries no longer operated in any activist sense, save for a few areas which unified the developing countries, such as in intellectual property. 
However, special and differential treatment was equally not an area for concessions to be made in the Round by the developing countries. It had become part of the system of trade rules embodied in the GATT and the codes emerging from the Tokyo Round. It was negotiating capital that could be used to extract concessions. The declaration launching the Round contained a clear and unequivocal reaffirmation of special and differential treatment as a principle of the trading system, even though possible reforms (including Article 18B) were raised early on by developed countries, and GSP graduation pressures against developing countries occurred outside of the Round, and even as it was continuing. How SDT could or could not be applied to the various enlargements in the coverage of the GATT which were occurring in the Round as it was being negotiated became the issue. How could new trade rules in agriculture, services and other areas be worked out in ways compatible with SDT? Refocusing SDT so that future benefits applied more to least developed countries was a further issue. Thus, despite a weakened commitment to SDT, it had become a central element of the system, and a principle that could still be used to extract concessions.

\subsection{The Uruguay Round Decisions on SDT}

In the Uruguay Round the decisions contain multiple elaborations on the earlier (Tokyo Round) notions of special and differential treatment for the reasons noted above. Having entered the system, developing countries sought comfort that any new elements entering the system would be consistent with it. Special benefits under the new arrangements in the name of SDT were assumed, sought, and offered; even if in reality there arrived late; were ad hoc in formalization are seemed little more than tokenesque compensation. 
In the preamble to most decisions there is a non concrete reference to special and differential treatment, acknowledging it as a central part of the GATT/WTO system of disciplines. Because of its acknowledged central role, concrete concessions were inevitably made in its name. Appendix A details these concessions, covering a range of areas; agriculture, textiles and clothing, technical barriers to trade, TRIMs, customs valuation, import licensing, subsidies/countervail, safeguards, services, TRIPs, dispute settlement, and measures for the least developed. These decisions brake down into a number of categories; delays on implementation and exceptions; preferential disciplines; flexibility in WTO disciplines and procedures; best efforts indications by the developed countries; technical assistance commitments; and specific SDT commitments in services. Many of the benefits under these decisions were explicitly focussed onto the least developed countries.

Most of these SDT elaborations were seemingly offered as a response to perceived special problems posed by the new disciplines for developing countries. A central problem was limited capability to implement any new arrangements, it seemed clear they needed both time and special help in complex areas such as intellectual property. Another was that with fragile and small manufacturing sectors, the adjustment costs they faced in adapting to a changed environment were disproportionately large. The result was compensation offered to developing countries for agreeing to new WTO disciplines.

However, by acknowledging these adjustment problems in developing countries, the new disciplines also opened the door to a wider debate on what the special problems of countries actually are as they integrate into the global economy and how they are best dealt with under SDT. And by focussing most of the benefits on the least developed the concept of tiering of SDT benefits across types of countries was also introduced. Many view these SDT provisions as little more than tokenesque special accommodation of developing country problems. Ad hoc they certainly are in design, and as Appendix A suggests, seemingly little applied, but the change in focus for SDT in the Uruguay 
Round is certainly there.

As the discussion in Appendix A shows, it is still too early to tell how far these provisions have been used, and with what effect. But little current use of a provision this does not necessarily indicate limited eventual use. In the TRIMs area, for instance, with a general review of TRIMs scheduled for the end of 1999, developing countries will likely delay any future requests for delayed implementation until closer to the date, especially with a possible launch of a new WTO negotiation in sight. In addition, the extent of SDT language in these decisions also mirrored to some degree a change in attitude towards developing country (and especially the least developed country) trade problems in some key developed countries, and this may portend more significant changes from these decisions than appears at first sight.

The picture painted by the material in Appendix A is, however, that a veritable smorgasbord of special and differential measures for developing countries were sprinkled throughout the Uruguay Round decisions. Special and differential changed from a focus on preferential access and special rights to protect, to one of responding to special adjustment difficulties in developing countries stemming from the implementation of WTO decisions. Preferences in implementation details were offered along with various best efforts commitments of help, including technical assistance aimed to help developing countries come into compliance with the decisions from the Round. While responses were clearly ad hoc, and these may seem largely tokenesque, the change in focus for SDT is clear.

\section{SDT IN A MILLENNIUM ROUND}

What is likely to be the focus of debate on SDT in a Millennium Round, and what could be fruitful 
directions to take in trying to elaborate on post Uruguay Round SDT? The possible answers to these questions depend in part, of what forces will shape any new Trade Round, assuming it is indeed launched.

\subsection{The Possible Content of a Millennium Round}

A third WTO Ministerial Meeting to be held in Seattle November 30-December 3, 1999 is widely expected to launch a new WTO Trade Round (the Millennium Round). ${ }^{4}$ The last WTO ministerial meeting (May 1998) resulted in agreement to develop positions on an agenda for future negotiations under a three stage process - issue identification (March (1999), development of proposals (Spring/Summer 1999), and finalizing of recommendations (Fall 1999). The range of issues to be covered in Seattle include the implementation of existing agreements, new negotiations in agriculture and services as required by the Uruguay Round, and other new negotiating topics.

A new Round would likely build on three broad elements. One is what is often referred to as the built in agenda (BIA); implementation issues and committed negotiations which come from the Uruguay Round decisions, including the launch of mini negotiations in agriculture and services by the end of 1999. Some argue that the requirement of monitoring and overseeing the implementation of the Uruguay Round decisions, plus new sectoral negotiations in agriculture and services could yield a package which would be sufficient to constitute a Round. Others doubt the significance of such package, and look for other elements which would need to be added to it.

Among other elements discussed are so-called new-new issues, issues which have accumulated since

${ }^{4}$ A complication in launching a new Round at this point is the situation in the US Congress, where there remains great caution towards any new international negotiation, and opposition to a grant of fast track authority. 
the Uruguay Round and which are supposedly to be put into a new trade negotiation package, although on each of these there has already been some backing away from concrete negotiation. A trade and environment negotiation, focussing on the rights of importing countries to use trade restrictions for environmental purposes, is one example. But developing countries have been cautious, and were successful in the 1996 Singapore Ministerial meeting in largely removing it from any future agenda, although it continues to circulate as a potential negotiating issue in a Round. Trade and labour standards is another issue (the rights of importing countries to use trade restrictions on imports of products which have been produced in ways which violate core labour standards, such as child or prison labour). The developing countries were also successful in the Singapore Ministerial Meetings in resisting pressures to start such a negotiation.

Broad ranging negotiations on investment initially are a third possibility. Discussion of a so-called MAI (Multilateral Agreement on Investment) has taken place in the OECD, although further negotiation has been prevented by pressures for cultural exceptions in countries such as France, Canada and Australia. Competition policy (see Lloyd and Simpson (1995)), is a further area of possible negotiation. The difficulties here are more those of defining the precise focus of such a negotiation than overcoming opposition to it. The aim is partly to move towards harmonization of countries' competition policies, but many countries, and especially developing countries, have no competition policy statutes. There are also issues of extraterritoriality which are of concern to developing countries. Finally, come issues associated with electronic commerce and the growth of the internet as a vehicle for conducting international trade, where many have argued that developing countries have much to gain.

A further key element to a possible Millennium Round will be opportunities for new reciprocal exchanges of concessions on trade barriers which go beyond what was achieved in the Uruguay 
Round. The list begins with agriculture, where existing quantitative and other restrictions have been converted into visible tariffs, many at very high levels ${ }^{5}$, such as the recently announced tariffs of over $1000 \%$ on certain types of rice in Japan. A possibility is thus for new reciprocal exchanges in the WTO focussed outside of manufacturing.

The developing countries main negotiating thrust thus far has been more negative than positive; to focus on keeping trade and environment and labour standards off the agenda, more so than seeking out new opportunities for enhanced trade through negotiated barrier reductions (in, say, agriculture and services). Also, the time overlap of implementation of Uruguay Round decisions and the December 1999 date of a possible launch have caused some countries to suggest that some of the time limits for Uruguay Round implementation in such areas as TRIMs and TRIPs should be substantially lengthened, or even converted into a permanent exemptions through negotiation in a new Round.

All these elements, in turn, interact with a number of further features of the post Uruguay Round environment. One is the elimination of MFA quota restrictions on textiles and apparel in the year 2004, which will leave in place tariffs on these items among the highest (on manufactured products) in many OECD countries, including the United States, and offering also the possibility of new reciprocal exchange. Developing countries are, however, fearful of what the post MFA regime could bring (dumping duties) and want to seek firm disciplines over any new trade restricting measures here. Another feature is the extensive tariff bindings undertaken by the developing countries in the Uruguay Round, with average product coverage of bindings moving from around $20 \%$ before the launch of the Uruguay Round to around $80 \%$ in these countries, again opening up further scope for

${ }^{5}$ See Ingco's (1996) discussion of tariffication in agriculture in the Uruguay Round which highlights dirty tariffication (replacement of existing measures by even more protective tariffs). 
negotiated barrier reductions. When services are added to this, some have argued that a new Round could offer possibilities for a considerable broadening of reciprocal exchange beyond that achieved in either the Uruguay Round or in earlier Rounds; and for the developing countries the issue is how best to aggressively to pursue such opportunities.

\subsection{SDT in a New Round}

Given all these possibilities what then could be the focus of efforts to refocus special and differential treatment in a new Millennium Round? If the Uruguay Round left SDT from earlier Rounds intact as a set of limited qualifications to GATT/WTO rules and disciplines, and elaborated on them in terms of implementation and technical assistance requirements, what may the Millennium Round produce?

\section{The Intellectual Coherence of SDT}

The Uruguay Round defacto refocused earlier SDT discussion from the 1960's onto adjustment and implementation capacity problems facing developing countries. Rather than ask what special rights to protect and special access benefits developing countries should have for their growth and development needs, the discussion was about what special treatment developing countries should receive as they integrate into the world economy, either through acceptance of WTO decisions, or through their own development. While motivated by these considerations, the Uruguay Round SDT decisions were nonetheless ad hoc, arrived at only late in the process, and lacked an integrated intellectual structure. Providing this may well be the central SDT challenge in the next Round.

The first step will be to systematically document and then obtain consensual agreement as to the ways in which developing countries do indeed face special problems which arise from their integration in 
the global economy. One set of such problems is their limited domestic policy capability, and their need, as a result, to use border measures as second best policy. Not all countries will simultaneously face all problems, and the issue of tiering of SDT benefits (discussed below) will quickly arise.

An example ${ }^{6}$ is environmental policy, an area where many developing countries have limited capacity to administer and effectively implement regulation and control. Investment screening, disallowed under full TRIMs implementation, may thus make good sense if heavy polluting investment is able to be screened out at the border. Another example is (the lack of) competition policy in lower income countries, and the use of second best border measures. Thus, if two or more companies collude in a small developing country market and raise prices, in the absence of competition law a duty on foreign supplies into the domestic market will recoup some of the collusive rents. Thus on second best grounds, such developing countries could even seek a new form of trade remedy, only available to them, anti-collusion duties. Such remedies, would, of course, be difficult to implement; determining collusion, and collusion margins, but these could operate as the mirror image of dumping duties, with determinations made of selling above (rather than below) cost, determinations of collusive margins, and duties imposed in such cases. ${ }^{7}$

In addition, the infant industry justifications of old are far from intellectually discounted, as are uninternalized externalities in endogenous growth discussion. A catalogue and fuller discussion of the precise circumstances where developing country protection of various forms is merited, and of what form, on what basis (time limits), and for precisely which countries seems to be the place to begin with discussion of any new SDT.

\footnotetext{
${ }^{6}$ I am grateful to Hesham Youssef for this example.

${ }^{7}$ There would, however, clearly be major administrative issues involved with making the necessary determinations.
} 


\section{Tiering of SDT benefits}

The older discussion of SDT saw developing countries as homogenous entities, who all had similar problems, which in turn were collectively different from those of the developed world; the joint needs for special rights to protect and special access rights. Since the Uruguay Round it has become common to stress how heterogenous the developing world has become over the years, and equally how the interests and circumstances of countries differ. In the Uruguay Round, these changes were implicitly recognized by heavily focussing many of the new SDT benefits towards the least developed countries. In a Millennium Round discussion, the prospect is for even more tiering of any SDT benefits raising the question of whether SDT as an overall concept can, in reality, survive such targeted delivery.

There has been discussion of the special problems of small countries, many of whom are also poor. If, for instance, one argues that as a first approximation the installation of an intellectual property regime involves a common fixed cost; there is a disproportionately larger cost borne by small countries and with only relatively small benefit to intellectual property holders. Some form of SDT exemption for small countries makes sense.

And the list continues with net food importing countries (already recognized as a special group in the Uruguay Round), land locked and mountainous countries, commodity exporters, war disrupted, and others. In all of these cases and more, arguments for special treatment can be made; whether they can all be accommodated within the general framework of a new SDT is the issue.

Moreover, delivery of SDT benefits only to the least developed is seen in the developed world as a less costly device than general SDT, and one with which they can go further. There has, for instance, 
been discussion of SDT proposals under which all least developed countries would be free of developed countries anti-dumping duties (either permanently, or for a period of, say, 20 years); such proposals applied to all developing countries would likely be unthinkable.

\section{SDT and Transparency}

A further likely element in a new SDT will be improvements in the transparency of operation of SDT commitments, and for developing countries to be more assertive in the use of their rights under SDT. Transparency might be attacked via an annual WTO SDT report, parallel to the TPRM exercise. This might make estimates of the significance of various elements in SDT, as well as highlight areas of non-implementation.

Alongside this would go a detailed assessment of where the SDT regime actually stands as the Millennium Round is launched. The complex and, in places, wide ranging Uruguay Round decisions need more scrutiny as to their take up and effectiveness. For instances, developing countries point to the SDT provisions in anti dumping under which developed countries committed to explore measures alternative to dumping before imposing duties on developing countries (presumably, competition policy). They claim to have requested information of developed countries as to which alternative measures have been investigated, only to be told there is no obligation to inform. The spirit of the original SDT provision seems clearly not being followed here, and there may be other areas.

Beyond this, further elements need to be considered in a general review of SDT. One is to better understand what the adjustment costs from implementing multilaterally agreed decisions in the developing countries actually are. Do such costs motivate time limited exemptions from disciplines, and if so which of them and for how long? Are adjustment costs largely a redistributive concern, and 
hence should compensation schemes within countries be used rather than WTO implementation delays? If so, how are they to be financed and delivered? The relatively poor record of OECD schemes which seek to identify and compensate trade impacted workers suggests problems here, and implementation delays may be political compensation more so than efficient policy.

How far any of these issues will actually be pursued in a new Round depends on how activist the developing countries choose to be on the SDT front, and whether such changes are negotiable with the developed countries. Developing countries may conclude they have higher priorities in negotiation elsewhere (preventing labour standards and environment, trade linkage, for instance); but a more activist stance in the agenda setting process for a Round might at least give them something to concede later (removing elements of a demand for SDT elaboration) in return for concrete benefits elsewhere (follow through on MFA elimination).

\section{SDT and new instruments and areas}

A further element to a SDT discussion in a new Round may also be to broaden discussion to cover the use of new instruments of interest and significance to developing countries, and particularly so to the least developed countries. Some of these possibilities are set out in 


\section{$\underline{\text { Table } 4}$}

\section{Some Possible Elements in an Enhancement of SDT in the Millennium Round}

1. Transparency/Monitoring/Use of SDT Commitments

- Annual SDT report (parallel to TPRM exercise) which estimates gains from SDT, highlights non implementation.

- More assertive use of existing commitments, even if loosely worded. They include SDT commitments to pursuit of alternative measures to anti dumping by developed countries, and seeking a possible strengthening (rewriting) of Part IV to provide some discipline on anti dumping is another.

2. Bound Margins of Preference (GSP)/Agriculture

- Explicit extension of GSP schemes to cover agriculture.

- Margins of preference towards developing/least developed on agriculture to be bound in WTO.

3. New Instrument Areas For Developing Countries (Anti Collusion Duties For Developing Countries)

- Several least developed countries experience collusive behaviour in their domestic markets with a small number of foreign suppliers. With no extra territorial reach of competition policy (or even any competition policies) increases in tariffs can extract a portion of collusive rents. Tax policy can be used for this purpose, but is usually constrained by double taxation treaties. Rights to use anti collusion duties, increasing tariffs above bound levels, for these purposes would be the issue.

4. Broadening Area Negotiations (Developing Country Property Rights)

- Broadening TRIPs negotiations to cover wider developing country property rights issues than just intellectual property could be in the interests of developing countries. Particularly key could be property rights related to traditional practices, including rights to compensation for use of traditional remedies in the biotechnology area. Wider environmental property rights protection might also be pursued. 
One raised above is a new form of developing country trade remedy, anti collusion duties; the idea being that where a small number of developed country suppliers collude in setting prices (or use other restrictive practices) in small developing country markets, the use of import duties may recoup part of the rents otherwise accruing abroad from the practice. These may be attacked through domestic tax policy or domestic competition law, but double taxation treaties may constrain the use of tax policy, and competition laws may not exist. Anti collusion duties, following a determination of collusive practices may be one way to proceed although the practical problems of making determinations of collusion and calculating collusion margins may be prohibitive. The idea in this category of SDT elaboration would be to develop a series of instruments only useable by developing (or least developed) countries, with the aim of improving their benefits from participation in the global economy.

A second possibility might be to seek more significant access benefits than currently available under GSP. This could involve various initiatives. One would be to explicitly extend GSP to agricultural products where, post tariffication in the Uruguay Round, barriers are high and hence margins of preference could be significant. Another might be to return to the issue of inter-developing country trade preferences (the older GSTP scheme) in a world of extensive tariff bindings in the developing countries and (even after liberalization) much higher tariffs in developing than OECD countries. If negotiated margins of preference were then bound, which was not the case with earlier GSP benefits, the OECD component of them might be graduation resistant. Another element might be to seek changes to the language of GATT Article 36 which indicates that a key purpose of the trading system is to facilitate the growth and development of developing countries as a way of possibly limiting the force of developed country anti dumping actions. 
A final possible element in such an approach to SDT would be to try to open up existing topic negotiations to wider discussion by covering areas advantageous to developing countries. For instance, logically, there is no good reason to limit discussion of links between property rights and trade to intellectual property; all manner of property rights could potentially be discussed.

Developing countries might want, for instance, to use TRIPs as a forum for asserting their property rights over traditional remedies and practices of various kinds, with compensation to governments when used. At a broader level property rights linked to environmental emissions could be a fruitful issue to raise; asserting that developed countries on a cumulative emission basis have long ago used up their rights to atmospheric emissions, and developing countries should be compensated for further developed country emissions. The link to trade in this case would be the trade implications of environmental treaties (Kyoto Protocol), and the international transfers involved. 


\section{CONCLUDING REMARKS}

Special and differential treatment (SDT) in the GATT/WTO in the Kennedy and Tokyo Rounds focussed on special rights to protect and special rights of access. In the Uruguay Round it was refocused towards special terms of implementation and technical assistance. The manifestation that SDT will take in the Millennium Round is not yet clear.

The research community has seemingly concluded that SDT has brought the developing countries relatively little. Special access rights via GSP were first constrained in various ways, then weakened quantitatively by multilateral tariff cuts, before being further eroded by their use as a graduation threat by developed countries to achieve other goals, (intellectual property protection). Special rights to protect, which many economists would argue were anyway harmful to economic performance, were more in the application of disciplines (18B) than their substance and have anyway been tightened. In the Uruguay Round, an extraordinarily long list of special terms of implementation, exceptions, technical assistance, and best endeavors for now seem not to translate into that much. Tokenesque is the description one frequently hears.

The Millennium Round poses a challenge for both developing countries and SDT. Will SDT in a new Round yield genuinely substantive benefits for developing countries, or will more tokenesque arrangements again be the result? Indeed, can special terms which are meaningful result from a framework of reciprocal exchange as in WTO? Opportunities exist for the developing countries; to refocus GSP on agriculture, to bind concessions, to actively use present SDT provisions to seek the creation of new instruments and arrangements. Whether this can be done through negotiated exchange, and whether there is the will on both sides to do so remains to be seen. 


\section{REFERENCES}

Collier, P., P. Guillaumont, S. Guillaumont, and J.W. Gunning (1997) "The Future of Lomé:

Europe's Role in African Growth" The World Economy, vol.20, no.3, May, pp.285-306.

Hudec, R.E. (1987) Developing Countries in the GATT Legal System, Gower for the Trade Policy Research Centre.

Hudec, R.E. (1990) "The Structure of South-south Trade Preferences in the 1988 GSTP

Agreement: Learning to Say MFMFN" in Whalley, ed., Developing Countries and The

Global Trading System, vol.1, Thematic Studies from a Ford Foundation Supported

Project (Macmillan, 1989) pp.210-237.

Ingco, M.D. (1996) “Tariffication in the Uruguay Round: How Much Liberalization?” The World Economy, vol.19, no.4, July, pp.425.446.

Karsenty, G. and Laird, S. (1987), “The Generalized System of Preferences: A Quantitative Assessment of the Direct Trade Effects and of Policy Options", UNCTAD Discussion Paper No.18, UNCTAD, Geneva.

Lloyd, P. and G. Sampson (1995) "Competition and Trade Policy: Identifying the Issues After the Uruguay Round" The World Economy, vol. 18, no.5, September, pp.681-707.

McPhee, C.R. (1989), “A Synthesis of the GSP Study Programme”, Mimeographed Report Prepared for UNCTAD.

Paparizo, A. (1998), "WTO Provisions on Least Developed Countries", Report Prepared for the Government of Nepal (mimeo).

Prebisch, R. (1962) “The Economic Development of Latin America and Its Principal Problems" Economic Bulletin for Latin America, vol.7, pp.1-22.

Rajapatirana, S. L.M. de la Mora and R.A. Yatawara (1997) "Political Economy of Trade Reforms 1965-1994: Latin American Style" The World Economy, vol.20, no.3, May, pp.307-337.

Sorsa, P. (1996) "Sub Saharan African Own Commitments in the Uruguay Round - Myth or Reality?" The World Economy, vol.19, no.3, pp.287-306.

UNCTAD (1998a) The Least Developed Countries Report, 1998; UN, Geneva.

UNCTAD (1998b) Trade and Development Report, 1998; UN, Geneva.

UNCTAD (1998c) “Accession to the WTO: The Process and The Issues”, Discussion Paper 16 July, 1998. 
Whalley, J. (1989) The Uruguay Round and Beyond: The Final Report from the Ford Foundation Project on Developing Countries and the Global Trading System, MacMillan, London.

Whalley, J. (1990) "Non-discriminatory Discrimination: Special and Differential Treatment Under the GATT for Developing Countries" Economic Journal, vol.100, no.403, December, pp.1318-1328.

WTO (1998a) Implementation of WTO Provisions In Favour of Developing Country Members, Note by the Secretariat, Geneva.

WTO (1998b) Communication from Egypt "Special and Differential Treatment for Developing Countries in the Multilateral Trading System".

Young, A. (1991), "Learning by Doing and the Dynamic Effects of International Trade", Quarterly Journal of Economics, No. 1106, pp.369-405. 


\section{APPENDIX A \\ The SDT decisions in the Uruguay Round}

\section{Agriculture}

In the agreement on agriculture, the developed countries committed to greater than average reductions in tariffs on products of interest to developing countries, such as tropical agricultural products, and speedier implementation of reductions. The agreement exempts least developed countries from making commitments to reduce export subsidies and domestic supports. Developing countries also have the right to delay the application of the Agreement for ten years following the entry into force of the Uruguay Round decisions. In the agreement on sanitary and phyto-sanitary measures, the so-called SPS Agreement, the notification procedures for these measures allow developing countries to identify where they may have problems and to request phased introduction.

\section{Textiles and Clothing}

In the Agreement on Textiles and Clothing (ATC), the annual quota growth rates carried over from the Multifibre Arrangement are to be advanced by one stage for all exporters whose restricted exports represent $1.2 \%$ or less of the total volume of the restricted trade of an importing country (as of the $31^{\text {st }}$ December 1991). Annual growth rates have been so advanced (by one stage) for Lesotho and Myanmar by Canada, and for Haiti by the United States. Significantly more favourable treatment for least developed countries where transitional safeguards are applied is written into the agreement, although no ATC safeguard actions involving exports from least developed countries have yet been notified to the WTO. 


\section{Technical Barriers to Trade}

In Technical Barriers to Trade, the TBT committee of the WTO can grant specific time limited exceptions from obligations to least developed countries, although no developing countries have yet requested any exception. Technical assistance and advice is also to be given on a priority basis to the least developed countries; in 1997 at its first tri-annual review the TBT committee agreed that assistance should be focussed in this way.

\section{Trade Related Investment Measures (TRIMs)}

In the Agreement on Trade Related Investment Measures, the Uruguay Round decisions state that developing countries can deviate temporarily from the provisions requiring that no country apply any trade related investment measures inconsistent with the provisions of Article 11 of GATT 1994 (and also Article 13 and the balance of payments provisions of GATT 1994 and the Uruguay Round). Least developed countries have these rights, but how far they have been used is not known. There is a special seven year transitional period for least developed countries for the elimination of prohibited trade related investment measures; currently Uganda is benefiting from this provision. In antidumping it was agreed that special regard should be given by developed countries to the situation in developing countries when considering the application of antidumping measures. Currently, the legislation of only one WTO member explicitly reflects this provision. ${ }^{8}$

${ }^{8}$ Although in Canada, where no special legislation has been written to this effect, Canadian trade officials have indicated in conversation that a policy has clearly evolved of less strict application of anti dumping measures against developing countries. Prior to recent duties on steel, Canada had not applied any anti dumping duties against developing countries since 1994. 


\section{Customs Valuation}

In the Agreement on Customs Valuation, the agreement affirms developing countries rights to delay implementation for up to five years, with delayed application of computed methods for a five year period. If this is not sufficient, a further extension can be granted, with further reservations applying to the sequential order of various computations. As Table $2 \mathrm{~A}$ indicates, a number of developing countries have already invoked these rights.

\section{Import Licensing}

In the area of Import Licencing, developing countries are allowed to delay the implementation of import licencing agreements by two years. Three least developed countries, Bangladesh, Burkina Faso and Myanmar have invoked these provisions. There are also special arrangements for least developed countries covering the allocation of quotas administered under import licencing arrangements.

\section{Subsidies/Countervail}

In the Agreement on Subsidies and Countervailing Measures, export subsidies are to be phased out over an 8 year period for the least developed countries, rather than the more stringent arrangements applying to other WTO members. The Prohibition of Subsidies contingent on the use of domestic rather than imported goods will not apply to least developed countries for a period of 8 years. Special rights also apply to the application of countervailing duty investigations, which are to be terminated if under a threshold on subsidies. Least developed countries have special rights in this area, with five countries having applied for such rights. 


\section{Safeguards}

In safeguards, it was agreed that measures should not be used against products from developing countries as long as their share of imports does not exceed 3\%. Four WTO members (Argentina, Brazil, Korea and the United States) who have applied safeguard measures have notified the exception of developing country exports which are below the threshold level. Developing countries also have the right to extend the period of use of safeguards measures by two years beyond the maximum period of 8 years which applies to other WTO members, although thus far no developing countries have invoked such rights.

\section{Services}

In services, special priority is to be given to the least developed countries and particular account was to be taken of the difficulties faced by them in making specific commitments. Special contact points for developing country suppliers to developed country markets were committed to. ${ }^{9}$ Least developed countries were given a year from the signing of the final act of the Uruguay Round in 1994 to submit their schedules of initial service commitments, a provision also present in the agreement on basic telecommunications and financial services. The WTO Secretariat has provided technical assistance to developing countries in this area, and WTO members are encouraged to give special consideration to opportunities for least developed countries to encourage foreign suppliers of telecommunications services to engage in transfer of technology.

${ }^{9}$ Although, in the Canadian case, even though these were established after the Round, seemingly no request for information has been made by any developing country. 


\section{TRIPs}

In TRIPs there is a special ten year transition period for least developed countries. There were to be incentives for enterprises and institutions in developed countries to promote technology transfer and technical and financial assistance in favour of developing countries, including in the preparation of legislation. Technical assistance in this area has been provided by the WTO and WIPO (The World Intellectual Property Organization).

\section{Dispute Settlement}

In dispute settlement the WTO Secretariat is to provide legal advice and assistance to least developed countries in the event of a dispute, with two consultants made specially available for this purpose. There are also a number of best endeavours clauses under which WTO members are to give special attention to particular problems and interests of developing countries, both in the setting up of panels and in the conduct of panel proceedings.

\section{Least Developed}

In decisions on measures in favour of least developed countries, consideration was to be given to improving preferential treatment for products of particular interest to developing countries, and at a high level meeting on integrated initiatives, in October 1997, thirteen WTO members announced new or additional preferential market access measures which they had taken in favour of least developed countries. 


\section{Table 1A}

\section{Special and Differential Treatment Provisions in the Uruguay Round Decisions ${ }^{10}$}

\section{Delays on Implementation/Exemptions}

- Agriculture - developing countries 10 years to implement (6 years developed countries) - least developed exempt from export subsidy, domestic support reductions.

- TBT - time limited exceptions can be granted to developing countries on request.

- SPS - time limited exceptions grantable to developing countries on request; least developed may delay implementation up to 5 years; developing 2 years.

- TRIMs - 5 year implementation developing countries, 7 years least developed countries, 2 year developed. Special developing country rights to time limited use of restricted TRIMs when measures consistent with Article 18B.

- Customs Valuation - 5 year delay on implementation; plus technical requirements on computation of duties.

- Import Licensing - 2 year delay to developing countries.

- Subsidies/Countervail - prohibited use of subsidies which require use of domestic over imported goods not to apply to developing countries for 5 years, to least developed for 8 years. Prohibited use of export subsidies contingent on export performance not to apply to least developed (or developing, $\$ 1,000 \mathrm{GDP} /$ capita). If countries become export competitive, subsidies to be phased out over 8 years for these countries. Other developing countries face 8 year phase out from WTO initiation, and 2 years where competitiveness criteria apply.

- Safeguards - developing countries can keep safeguards measures for 10 years (8 years other countries). Special rights granted to reuse a measure against a product previously covered by a safeguards action.

- TRIPs - all developing countries have 4 year delay on implementation. Implementation of certain patent protection can be delayed further 5 years. Least developed, 10 year delay in implementation.

\section{Preferential Disciplines}

- Agriculture - 24\% tariff cut average (min 10\%) for developing countries (36, 15 for developed). Developing countries allowed to retain import restrictions on some staples. Reduced reduction in domestic supports (13.3\% as against $20 \%$ for developed countries). Lower reduction required in export subsidies (24\% versus $36 \%$ for developed countries). Least developed countries exempt from some transport related export subsidy commitments.

- Subsidies/Countervail - more generous de minimis provision on countervailing duty investigations ( $2 \%$ versus $1 \%$ subsidy for developed countries; $4 \%$ import volume, subject to a $9 \%$ cumulation rule). Least developed ( $<\$ 1,000 \mathrm{GDP} /$ capita) have $3 \%$ de minimis for eight years.

${ }^{10}$ This Table draws on information presented in Paparizo (1998), UNCTAD (1998a,c), WTO (1998). 
- Safeguards - de minimis on safeguards actions against developing country exports of 3\%, with $9 \%$ developing country cumulation rule.

3. Flexibility in WTO Disciplines/Procedures

- Article 18B - simplified consultation procedures may be requested for least developed.

- TPRM - simplified procedures under TPRM available if also under BoP consultation; applies to all developing countries.

- Agriculture - measures to encourage rural development exempt from disciplines on domestic support for developing countries. Developing countries exempt from Article 11 restrictions on export bans.

- Dispute Settlement - developing countries have rights to at least one developing country panellist. Time limits for stages of dispute settlement can be extended if a developing country is the defendant. Panel reports are to indicate how SDT has been taken into account. Special situation of least developed countries to be taken into account at all stages of dispute settlement.

\section{Best Efforts}

- Agriculture - developed countries to take into account developing country interests in implementing market access decisions.

- mechanisms to be established to preserve food availability in net food importing countries and least developed.

- Textiles/Apparel - least developed to be accorded more favourable treatment in the MFA phase out, also to apply to wool producing developing countries.

Anti Dumping - special account to be taken by developed countries of developing country interests.

- Subsidies/Countervail - WTO Committee on Subsidies/Countervail stands ready to review measures against specific developing countries if requested.

- TRIPs - developed countries to provide incentives for technology transfer by their companies to least developed.

\section{Technical Assistance}

- Commitments in a number of areas (agreements) - BoP, SPS, TBT, Customs Valuation, Preshipment, TRIPs, Dispute Settlement, TPRM, GATS.

\section{Services (GATS)}

- Developed countries to establish (within 2 years) special contact points for developing country service suppliers.

- More favourable treatment on sectoral coverage requirements on regional integration arrangements for developing countries.

- Development objectives to be taken into account for developing countries in future subsidy negotiation.

- Flexibility on commitments to be made by developing countries in future negotiating rounds. 


\section{Table 2A}

\section{The Extent of Implementation of Uruguay Round SDT Decisions ${ }^{11}$}

1. Delays/Exemptions

$\begin{array}{ll}\text { Agriculture } & \text { - Least developed exemptions under export } \\ & \text { Subsidies/supports reflected in their schedules. } \\ \text { TBT } & \text { - No delays seem to have been requested by any } \\ & \text { Developing country. } \\ \text { SPS } & \text { - No developing country seems to have requested delays. } \\ \text { TRIMs } & \text { - Uganda has requested a delay. } \\ \text { Customs Valuation } & - \text { 12 least developed countries requested delays. } \\ \text { Import licensing } & \text { - Three least developed countries (Bangladesh, Burkina Faso, } \\ & \text { Myanmar) invoked longer implementation period. } \\ \text { Subsidies/Countervail } & \text { - Least developed have right to longer termination; no necessity } \\ & \text { to invoke. } \\ \text { Safeguards } & \text { - No least developed country has used safeguard measures. } \\ \text { TRIPs } & - \text { Automatic right to delayed implementation, no need to invoke. }\end{array}$

2. Preferential Disciplines

Reflected directly in WTO disciplines.

3. Flexibility

BoP/Article 18B

- Bangladesh requested simplified consultations, but was denied.

TPRM - No information on use of simplified procedures.

Agriculture - Least developed exempt from domestic support disciplines; special exemption from rural development measures not relevant for them.

Dispute Settlement - No least developed countries seems to have been involved in dispute settlement.

4. Best Efforts

Agriculture - Unclear extent to which developing country interests taken I into account in implementing developed country schedules. No information/study available. Net food/food availability commitment reaffirmed by developed countries; actions unclear.

${ }^{11}$ This information presented in this table draws on Table 14 pp.74-77 of the 1998 UNCTAD Least Developed Countries Report (UNCTAD (1998a)), and WTO (1998). 
Textiles/Apparel - First stage phase out implementation by developed countries criticized by developing countries as lacking in substance; preferential implementation towards least developed unclear (besides US and Canadian actions referred to in text).

Anti Dumping - Legislation of only one WTO member reflects special consideration committed to.

Subsidies/Countervail - No request known.

TRIPs

- Technical assistance from WTO, WIPO; developed country incentive measures undocumented.

5. Technical Assistance [\$ amounts and effectiveness unknown]
BoP
- Unknown.
SPS
- Unknown.
TBT
- Implementation pending.
Customs Valuation
- Provided by World Customs Organization.
Preshipment Unknown
- Some provided by World Bank.
TRIPs
- Provided by WTO \& WIPO.
Dispute Settlement
- Consultants made available by WTO - no dispute cases for least developed (outside bananas).
TPRM
- Unknown.
GATS
- WTO provided assistance.

6. Services

Contact Points - No information.

Regional Integration - Unclear, no information on provisions used.

\section{APPENDIX B}

\section{Evaluating the Impacts of Special and Differential Treatment}

An evaluation of what developing countries have achieved in earlier negotiating Rounds under special and differential is also relevant to what they may seek under the SDT heading in a new Millennium Round. Many countries believe they have achieved little of value. If this is so, many may understandably be reluctant to go further down the SDT route. Most literature on SDT focusses on its pre Uruguay Round form; rights to protect and rights of access, even though in many ways it is now the post Uruguay Round SDT that is more relevant. 


\section{Special Rights to Protect}

On special rights to protect, in the 1950's it was widely believed that protection of domestic markets by developing countries was essential for growth and development. This reflected the belief that economic growth inevitably involved a transformation of the economy from a largely agricultural/agrarian (and rural) economy to one which is more heavily industrialized.

To achieve industrialization it was believed that a secure domestic market was needed for fledgling industries, and that this could only be achieved behind the protective barrier of trade protection.

These views were supported at an intellectual level by what subsequently became known as the Lewis Model. Arthur Lewis, writing in 1954, produced a series of papers based on his experiences in the Caribbean (primarily in Jamaica). Lewis's view of the world was that in developing countries there was surplus labour in the agricultural sector and its presence reflected agriculture activity conducted according to communal or family based farming patterns, under which labour was paid its average rather than its marginal product. In the modern sector labour was paid its marginal product, and moving labour from the agricultural to the modern sector would be efficiency improving in terms of overall resource allocation. In the Lewis view of the world, therefore, protection would be good because it would generate a desirable resource transfer.

These views received substantial reinforcement from a number of quarters. An argument strongly held among trade negotiators was that the balance of payments problems of developing countries were severe and endemic, and hence with inconvertible currencies and large balance of payments problems any liberalization would simply result in increased import flows and even more severe 
payments difficulties. Under this view of the world, liberalization for these countries was simply impossible.

Infant industry arguments also found their way into these debates. If there are economies of scale then a period of protection may be needed to allow domestic industry to establish itself and to exploit the scale economies. It was common at the time to point to the experience of Japan as showing that growth in the presence of scale economies is fuelled by protection of this type.

These old arguments for special rights to protect under SDT later clashed both with the emerging neo-classicism dominating academic economic literature from the 1960's and classical views on the gains from trade going back 150 years or more. Under a classical view of trade, the purpose of trade is to achieve benefits through exchange; and a small open price taking economy which takes prices as given on world markets and has no influence over its terms of trade maximizes these gains through free trade. Any protection is bad, since an import tariff acts akin to a tax on export activities.

\section{Outward Orientation and SDT}

Classical arguments on the gains from trade were rediscovered in the 1980's in the SDT discussion when it was noted that those economies which had been relatively successful in terms of trade and GDP growth were those which had pursued outward oriented policies (Korea, Taiwan). There was debate at the time about what had actually happened in economies such as Korea, although the Taiwanese case was seen as clearer. In order to grow and industrialize it became believed that outward oriented policies rather than protectionist trade policies were the route to take. Under protection domestic interests would capture the trade policy process and perpetuate protectionist trade policies for a long period of time. Even if infant industry arguments were used to rationalize 
protection, as they became children and fully mature adults the infants would continue to seek and benefit from protection. It was thus argued that the forms of trade policy which many developing countries had used and justified under SDT compounded the forgone gains from trade. For instance, with import quotas allocated to small number of firms (or even only one firm) domestic market structure problems were created within developing country markets, which intensified the resource allocation problem.

For all these reasons, therefore, by the mid 1980's, and with the installation of meritocratic trade officials in a number of developing countries, the intellectual rationale for special and differential treatment began to erode and the belief began to spread that SDT had been adverse to developing country interests. This is despite the fact that in more recent years there has been something of a resurgence in intellectual debate back towards rationales for developing country protection. Thus, in the literature on endogenous growth (see Young (1991)), where there are uninternalized externalities within economies, there are rationales for internalization to be pursued through a protective tariff. Tariff policy can under some circumstances be good. Interlinkages between market structure and trade policy have also been discussed in the literature. On balance, for most economists free trade still seems the appropriate policy posture, particularly for smaller countries, but special rights to protect are still be a practice which find a rationale in the literature.

In WTO terms, because both Articles 18A and Article 18C involve compensation and retaliation, and it is Article 18B that has come to be regarded as the developing countries major special right to protect. The benefits of $18 \mathrm{~B}$ lie, however, as much in its application as in the legal terms. In the past, and before the conclusion of the Uruguay Round, consultations under Article 18B were often little more than pro forma, and notification to the GATT of Article 18B justified measures was incomplete. In turn, Uruguay Round debate on Article 18B involved how to achieve stronger 
application of existing disciplines as more than reassessment of formal benefits in this area.

Thus what one counts as a benefit to developing countries under Article $18 \mathrm{~B}$ is affected by how one sees their interest. If free trade is good, and international agreements such as the WTO are needed to restrain protection seeking domestic pressure groups, any form of preferential treatment for developing countries (as under 18B) appears bad. On the other hand, if one believes that freedom to protect is essential to the development process, then more lax disciplines in this area benefit developing countries. The evaluation issue is whether or not one believes that weaker GATT/WTO disciplines on protection are really in the interests of developing countries.

\section{Access Benefits of SDT}

On the access side, there is more unanimity of view as to the impacts of SDT compared to special rights to protect. If developing countries can obtain preferential access and improve their terms of access to markets abroad, they are better off. The difficulty is that such access, particularly under the arrangements embodied in the GSP, tends to be unbound and hence is insecure. A recent piece by McLaren (1997), for instance, examines the case of smaller countries negotiating access improvements with large countries. Since they adjust into these access improvements and face adjustment costs in unwinding them if the benefits are withdrawn, there are circumstances under which they could be worse off. This argument suggests some hesitation in developing countries, in actively pursuing access improvements, but generally speaking the benefits are seen in the literature as clear, and especially so if the benefits are bound.

As far as access benefits under SDT are concerned, the issue comes down essentially to the benefits from the generalized system of preferences, GSP. A problem for the developing countries has always been that GSP defines a series of unilateral concessional measures introduced by 
individual developed countries. Preferences are not bound in GATT/WTO, and can and have been unilaterally withdrawn by developed countries. The threat of graduation from GSP has also frequently been used by developed countries as a mechanism to force developing countries to make changes in their domestic policy regime, most notably in the intellectual property area. The issue with GSP, therefore, is not only what developing countries may or may not have gained from tariff preferences, but what the creation of a non-GATT bound instrument, whose threatened withdrawal can be used to force further concessions, has cost them.

Most OECD countries grant GSP preferences, along with a small number of other countries, including (still) Russia. Countries receiving them are most of the developing countries, although various exclusions now apply in the key schemes (of the EU, US and Japan). It is also the case that with progressive MFN tariff reductions in these countries, the value of these preferences has been significantly reduced. Product exclusions in these schemes have also been a factor; mainly in the food, textile and petroleum products areas, with further limitations applying and triggered by mechanisms which limit the benefits. Thus, in the United States, competitive need criteria withdraw eligibility to GSP when countries become competitive in products in question. There have also been rules of origin applied under many country GSP schemes, requiring qualifying products to be substantially produced or transformed in the country receiving the preference. These rules of origin have been a longstanding issue in the special preferences committee in the UNCTAD which meets every year to review changes in GSP schemes.

The benefits that GSP schemes have yielded for developing countries have been the subject of a body of research which seeks to quantify them using a range of techniques and approaches. The picture that emerges is that benefits seem to be modest in aggregate, and are more important for some countries than others. Thus, Karsenty and Laird (1987) using detailed UNCTAD data 
concluded that in 1983 imports by GSP donor countries from GSP receiver countries were only $2 \%$ higher than they otherwise would have been. Moreover, even full extension to all products GSP schemes could only increase these gains by a factor of 3 .

McPhee (1989) reported expost estimates of GSP impacts on beneficiary country export earnings, concluding that GSP had had at best a modest positive impact on the exports of these countries in the short run. More country focussed analysis (also by McPhee (1989)) on Brazil, Malaysia, Korea and Thailand examined the impacts of GSP on industrialization and growth, and concluded that the impacts of GSP on these countries' performance had been only small. The data indicated that for these countries only about $1 / 7$ th of their exports actually receive GSP treatment. For some of these countries, their share of production which is exported is also relatively small, leading to only small growth contributions from GSP. Karsenty and Laird (1987) also showed that the benefits to developing countries from GSP were heavily concentrated. In their analysis, over $50 \%$ of GSP benefits went to four beneficiaries, Hong Kong, Korea, Taiwan and Brazil. Other studies have also shown that in the EC imports from non beneficiaries have grown faster than those from GSP beneficiaries.

The overall assessment, therefore, of the research community seems to be that benefits to developing countries from GSP have been modest at best; they are restricted by product coverage and margins of preferences are small, in part because the developed country tariffs are low. When combined with a seeming fragility of GSP schemes under graduation pressures, the overall benefits to developing countries seem to many to be of limited consequence.

\section{Post Uruguay Round SDT}

If the concrete benefits to developing countries from the pre Uruguay Round forms of SDT seem 
small, what can be said of the SDT in the Uruguay Round decisions themselves. The initial null hypothesis would seem to be that compared to access benefits under GSP, the value of delays, special exceptions, best efforts indications, and technical assistance are likely to be even smaller in terms of concrete development benefits. Indeed, there is even an argument that in some ways they can even be negative; for instance, if technical assistance resources were redirected from other areas to support, say, installing an intellectual property regime which largely benefited developed country intellectual property owners.

The initial indications from the first five years of operation of Uruguay Round decisions unfortunately still provide an incomplete picture both on use of SDT provisions and their impact. The follow through by developed countries on best efforts endeavours and even concrete commitments seems to have been limited. On the other hand, in some countries there seems to have been a clear change in attitude in approach to developing country trade problems (and especially so to the least developed) coincident with end of the Uruguay Round. ${ }^{12}$

In terms of take up and invocation of the various Uruguay Round SDT provisions, in developing countries the picture seems clearly to be one of limited use. The most extensive use of delay provisions is in customs valuation (up to 12 least developed countries). There has been some limited advancement of MFA phase out provisions for least developed countries by one stage (for 3 countries). Four developed countries have notified the WTO of a new developing country de minimis thresholds for safeguards. One developed country has up written anti dumping legislation to require special regard be paid to the situation of developing countries. But elsewhere the one request for an expedited BoP consultation (by Bangladesh) under special SDT rules was denied.

\footnotetext{
${ }^{12}$ Canada's approach to anti dumping actions against developing countries, noted earlier, seems to be one example.
} 
The extension of TRIMs limitation on the use of subsidies on domestic rather than foreign goods to eight years does not appear to have generated any specific developing country response.

If the literature conclusion that SDT before the Uruguay Round yielded little of concrete benefit to the developing countries, the Uruguay Round SDT provisions seem equally to have yielded limited substantive benefit, but it has to be emphasized how clouded the picture is for such an assessment. The issue this poses may well be whether it really is worth the developing country effort to drive towards reinvigorating SDT for a third time, or whether to leave things be and focus negotiating efforts elsewhere. 